\title{
Tramadol effects on clinical variables and the mechanical nociceptive threshold in horses
}

\author{
Efeitos do tramadol sobre variáveis clínicas e limiar nociceptivo mecânico em equinos
}

\author{
Leandro Guimarães Franco ${ }^{\mathrm{I}}$ Juan Carlos Duque Moreno" Antônio Raphael Teixeira Neto ${ }^{\mathrm{III}}$ \\ Moisés Caetano e Souza ${ }^{\text {II }}$ Luiz Antônio Franco da Silva ${ }^{\text {II }}$
}

\begin{abstract}
This study assessed the clinical effects and the mechanical antinociceptive potential of intravenous (IV) tramadol in horses.A blinded and randomized study was designed with 7 horses treated with 1 (Tr1), 2 (Tr2) or $3(\operatorname{Tr} 3) \mathrm{mg} \mathrm{kg}^{-1}$ of tramadol $I V$. The heart rate, respiratory rate $\left(f_{R}\right)$, arterial pressure, degree of sedation, gastrointestinal motility (GI), behavior changes and the mechanical nociceptive threshold (MNT) were evaluated. The MNT was determined with von Frey device method.Tr3 had a significant increase in their $f_{R}$ and more pronounced behavioral changes than other treatments.The $\operatorname{Tr} 1$ showed a significant increase in arterial pressure. The GI reduced significantly, mainly in Tr2. The tramadol did not change the MNT of the horses.The clinical alterations observed with the different treatments were considered mild and transitory, being most evident in Tr2. However the tramadol did not have any analgesic effect with any of the doses evaluated.
\end{abstract}

Keywords: analgesia, horse, opioid, von Frey device.

RESUMO

Avaliaram-se os efeitos clínicos e o potencial antinociceptivo mecânico de diferentes doses de tramadol administradas por via intravenosa (IV) em equinos. Sete animais foram tratados com 1 (Tr1), 2 (Tr2) ou 3 (Tr3) mg $\mathrm{kg}^{-1} \mathrm{de}$ tramadol IV em um estudo cruzado do tipo cego e randomizado. Foram avaliados frequência cardíaca, frequência respiratória, temperatura retal, pressão arterial, nível de sedação, motilidade gastrointestinal, alterações comportamentais e limiar antinociceptivo mecânico (Von Frey). As principais alterações evidenciadas pela administração do tramadol concentram-se no aumento na frequência respiratória em $\operatorname{Tr} 3$, aumento significativo da pressão arterial em Tr1 e redução da motilidade gastrointestinal, mais pronunciada em Tr2. O tramadol não promoveu alteração significativa no limiar nociceptivo mecânico. As alterações clínicas observadas nos diferentes tratamentos foram consideradas leves e transitórias. Diante dos resultados, pode-se concluir que o tramadol não apresentou efeito antinociceptivo passível de ser avaliado pelo método empregado no presente estudo, em nenhum dos tratamentos.

Palavras-chave: analgesia, equino, opioide, von Frey.

\section{INTRODUCTION}

Although it is extensively used to control light and moderate pain in humans, the use of tramadol in veterinary patients is relatively recent (NATALINI \& ROBINSON, 2000). In horses, tramadol is quickly metabolized mainly into N-desmethyltramadol (M2), which is pharmacologically inactive, and its clinical efficiency is unclear in this species as compared to humans (GIORGI et al., 2007). It is believed that the analgesic effects of tramadol can be associated with other mechanisms of action, such as the modulation of the serotoninergic and monoaminergic pathways (NATALINI\& ROBINSON, 2000; DHANJAL et al., 2009; KNYCH et al., 2013).

The route of administration of the tramadol in horses and the model of nociceptive stimulation seem to influence the observed analgesic effects. When a $2 \mathrm{mg} \mathrm{kg}^{-1}$ dose was administered by epidural injection, with no nociceptive evaluation, the drug produced plasma concentrations $>100$ ng $\mathrm{mL}^{-1}$; if it was extrapolated to human beings, such concentrations would be enough to achieve

\footnotetext{
IDepartamento de Ciências Agrárias e Ambientais (DCAA), Universidade Estadual de Santa Cruz (UESC), Campus Soane Nazaré de Andrade, Rodovia Jorge Amado, 45662-900, Ilhéus, BA, Brasil. E-mail: lg.franco@yahoo.com.br. Autor para correspondência.

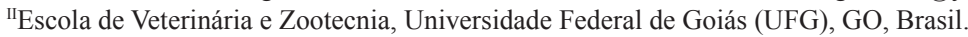

IIIUniversidade de Brasília (UnB), Brasília, DF, Brasil.
} 
significant analgesia (GIORGI et al., 2010). Recently, KNYCH et al. (2013) observed plasma tramadol concentrations greater than those necessary for analgesia in human patients for doses of 0.5 to $3.0 \mathrm{mg}$ $\mathrm{kg}^{-1}$ in horses. NATALINI \& ROBINSON (2000), when evaluating the analgesic effects of tramadol after the administration of $1 \mathrm{mg} \mathrm{kg}^{-1}$ by epidural injection, observed the presence of a significant analgesia to electrical stimulation comparable to that provided by morphine. As for intravenous injection, a original study that used a $2 \mathrm{mg} \mathrm{kg}^{-1}$ dose of tramadol did not reveal analgesic effects in healthy horses subjected to thermal stimulation (DHANJAL et al., 2009).

Pressure algometry, through mechanical stimulation, is repeatable and provides quantitative information on nociception (HAUSSLER \& ERB, 2006). One method, von Frey filaments, described by Maximilian von Frey in 1896, has been used with relative safety and repeatability for the evaluation of cutaneous sensitivity in horses (REDUA et al., 2002; OLESKOVICZ et al., 2006) and dogs (DUQUE et al., 2004, KUKANICH \& PAPICH, 2011). As an alternative to the von Frey filaments, electronic methods have been developed and tested on other species (CUNHA et al., 2004; DENADAISOUZA et al., 2009) and showed advantages over the classic method, including a reduction in the number of attempts required to evaluate the nociceptive threshold, the elimination of problems in the standardization of the filaments.

The objectives of this study were to evaluate the clinical and cardiorespiratory effects and the antinociceptive mechanic potential of three different doses of tramadol administered intravenously in horses. It was hypothesized that tramadol would have antinoceptive effects in horses undergoing mechanical stimulation.

\section{MATERIAL AND METHODS}

The experiment was conducted after its approval by the institutional animal care and use committee.Seven healthy mixed-breed adult horses of either sex, aged 9-13 years old and weighing $318 \pm 36 \mathrm{~kg}$, were used in the study. The horses were deemed to be healthy on the basis of physical examination and standard laboratory tests.

The horses were acclimated by daily restraint in the stocks, for 15 days before the beginning of the experiment. The sequence of treatments for each animal was randomly determined taking care that each animal was not allocated to the same treatment more than once. The evaluators were blinded to the sequence of treatments until the end of the experiment.Each horse was studied on three occasions using a randomized crossover design, with a minimum of 15 days between experiments.

Tramadol hydrochloride $5 \%$ a was prepared with a final concentration of $10 \mathrm{mg} \mathrm{mL}^{-1}$ of tramadol in saline solution and infused over 10 minutes from a syringe pump $\mathrm{p}^{\mathrm{b}}$. The horses were distributed into three treatments named $\operatorname{Tr} 1, \operatorname{Tr} 2$ and $\operatorname{Tr} 3$ to receive 1,2 , and $3 \mathrm{mg} \mathrm{kg}^{-1}$ doses of tramadol IV, respectively. The evaluations were performed immediately before the IV injection and 5, 10, 20, 40, 60, 90, 120, and 180 minutes after the application of tramadol (T0, T5, T10, T20, T40, T60, T90, T120, T180, respectively).

A computer was used to record and analyze the electrocardiogram $(\mathrm{ECG})^{\mathrm{c}}$. An oscillometric monitor $^{\mathrm{d}}$ was attached to a cuff on the tail of the horse to measure arterial blood pressure. The width of the cuff was $25-30 \%$ of the tail circumference.

The anterior region of the coronary band of the left forelimb was prepared for assessment of the nociceptive threshold. This was evaluated using a digital analgesiometer based on the von Frey method ${ }^{\mathrm{e}}$. The equipment consists of a pressure transducer adapted with a cable to a digital counter with $0.1 \mathrm{~g}$ precision which records the weight (grams force, gf) applied. This device includes a transducer arm with a force measurement capacity of 0.1 to $1000 \mathrm{gf}(0.98 \mathrm{mN}$ to $9.81 \mathrm{~N})$. Mechanical threshold were made by the same operator, who blinded to the actual readings obtained.

For the basal values, it was calculated the arithmetic mean of three measurements performed at 10-minute intervals. It was measured heart rate from the ECG (HR - beats minute $\left.{ }^{-1}\right)$; and respiratory rate $\left(f_{R}-\right.$ breaths minute $\left.{ }^{-1}\right)$ by counting the chest movements over 1 minute. The systolic arterial pressure (SAP), diastolic arterial pressure (DAP) and mean arterial pressure (MAP) were obtained from the noninvasive oscillometric device.

The degree of sedation was determined by measuring head position (HP), considering the distanceof nostrils in relation to the ground with a ruler fixed to the stock. The baseline value of the head position was measured in triplicate at 10-minute intervals, a result of the arithmetic mean of the measurements. The operator recorded the measure at a minimal distance of 3 meters from the animal using a measuring tape tied to the stock, aiming not to provoke any stimulus. As the animals were conditioned to the management, a few minutes after being restrained in the stock they seemed calm without abrupt movements with the head. If there 
were discrepant values due to some unexpected reaction of the animal, new measurements were taken. The results were converted to percentages to avoid the variability caused by the size differences between the horses (RINGER et al., 2012).

Gastrointestinal motility (GI) was evaluated by auscultation using a modification of the method described by SINGH et al. (1997). Four abdominal quadrants (upper and lower on the left and right sides) were ausculted for at least 30 seconds ( 60 seconds in the case of low frequency) at two sites per quadrant by one person who was not aware of the treatment administered to each horse.

The mechanical nociceptive threshold (MNT) was defined as the lowest force of mechanical stimulation that produced a response. The MNT, in grams-force, was measured by determining the force applied to the coronary band until the stimulated limb was lifted off the ground. Positive responses were shoulder and withdrawal of the left foot.A simple withdrawal reflex upon first touch to the skin was not accepted as an end point. To minimize the variations between the measurements, five evaluations were performed for each time, and the mean of the 3 closest values was then calculated. The horses had blinders on, so that they could not see the stimulus being applied. Behavioral alterations were reported descriptively.
The data were showed as mean \pm standard deviations. The software Sigma Stat - Windows was employed to analyze the data. The normal data were submitted to the Analysis of Variance (ANOVA) for repeated measurements, followed by the StudentNewman-Keuls (SNK) test for comparison of the intervals inside each treatment, and a one-way ANOVA followed by the SNK test was used for comparison among the treatments for each interval. For the data that did not have a normal distribution, the Kruskal Wallis' test was used followed by the SNK test. The results for the GI motility scores were analyzed by the Kruskal Wallis' test followed by SNK test. The level of significance was taken at 5\% $(\mathrm{P}<0.05)$.

\section{RESULTS AND DISCUSSION}

The detailed results for the $H R, f_{R} S A P$, MAP and DAP are in table 1. The tramadol did not affect the HR, regardless of the administered dose. No difference were detected between the three treatments $(\mathrm{P}>0.05)$. No changes in the ECG were recorded. Similar results were described by DHANJAL et al. (2009) after evaluating the effects of cumulative doses of tramadol (maximum of $1.6 \mathrm{mg} \mathrm{kg} \mathrm{kg}^{-1}$ ) in horses. For doses higher than those utilized in this

Table 1 - Mean [SD] cardiorespiratory variables of the horses treated with $1 \mathrm{mg} \mathrm{kg}^{-1}(\operatorname{Tr} 1), 2 \mathrm{mg} \mathrm{kg}^{-1}$ (Tr2) or $3 \mathrm{mg} \mathrm{kg}^{-1}(\operatorname{Tr} 3)$ of tramadol intravenously.

\begin{tabular}{|c|c|c|c|c|c|c|c|c|c|c|c|}
\hline Variables & Doses & T0 & $\mathrm{T} 5$ & $\mathrm{~T} 10$ & $\mathrm{~T} 20$ & $\mathrm{~T} 40$ & T60 & Т90 & T120 & $\mathrm{T} 150$ & $\mathrm{~T} 180$ \\
\hline \multirow{3}{*}{$\begin{array}{l}\text { HR } \\
\text { Beats } \min ^{-1}\end{array}$} & $\operatorname{Tr} 1$ & $38[9]$ & $37[6]$ & $37[7]$ & $38[9]$ & $35[5]$ & $36[4]$ & $35[5]$ & $35[5]$ & $34[4]$ & $34[5]$ \\
\hline & $\operatorname{Tr} 2$ & $36[6]$ & $42[14]$ & $40[11]$ & $41[9]$ & $38[6]$ & $39[10]$ & $38[7]$ & $38[5]$ & $39[8]$ & $37[6]$ \\
\hline & $\operatorname{Tr} 3$ & $36[6]$ & $38[7]$ & $40[5]$ & $39[6]$ & $38[5]$ & $36[7]$ & $35[4]$ & $35[5]$ & $35[5]$ & $36[7]$ \\
\hline \multirow{3}{*}{$\begin{array}{l}\mathrm{f}_{\mathrm{R}} \\
\text { breathsmin }^{-1}\end{array}$} & $\operatorname{Tr} 1$ & $23[9]$ & $29[19]$ & $24[17]$ & $25[11]$ & $25[15]$ & $33[31]$ & $27[17]$ & $27[13]$ & $29[8]$ & $31[8]$ \\
\hline & $\operatorname{Tr} 2$ & $22[6]$ & $29[11]$ & $24[10]$ & $26[10]$ & $26[8]$ & $24[9]$ & $21[4]$ & $22[4]$ & $20[4]$ & $23[9]$ \\
\hline & $\operatorname{Tr} 3$ & $22[5]$ & $36 *[15]$ & $35 *[17]$ & $35 *[18]$ & $30[14]$ & $34 *[20]$ & $29[16]$ & $27[14]$ & $23[6]$ & $21[9]$ \\
\hline \multirow{3}{*}{$\begin{array}{l}\text { SAP } \\
\mathrm{mmHg}\end{array}$} & $\operatorname{Tr} 1$ & $104[5]$ & $123 *[19]$ & $119 *[16]$ & $125^{*}[13]$ & $121 *[20]$ & $132 *[37]$ & $122 *[18]$ & $116^{*}[12]$ & $110 *[14]$ & $111 *[13]$ \\
\hline & $\operatorname{Tr} 2$ & $108[8]$ & $123 *[14]$ & $121[13]$ & $121[20]$ & $117[18]$ & $115[18]$ & $112[16]$ & $115[21]$ & $109[15]$ & $112[19]$ \\
\hline & $\operatorname{Tr} 3$ & $109[12]$ & $121[9]$ & $122[6]$ & $118[16]$ & $121[15]$ & $115[16]$ & $117[17]$ & $115[15]$ & $115[16]$ & $117[22]$ \\
\hline \multirow{3}{*}{$\begin{array}{l}\text { DAP } \\
\mathrm{mmHg}\end{array}$} & $\operatorname{Tr} 1$ & $57[4]$ & $71 *[14]$ & $69 *[9]$ & $73 *[11]$ & $68 *[10]$ & $75 *[25]$ & $70 *[13]$ & $66 *[11]$ & $63[11]$ & $63[10]$ \\
\hline & $\operatorname{Tr} 2$ & $61[7]$ & $73 *[13]$ & $72[12]$ & $68[14]$ & $65[11]$ & $65[12]$ & $65[10]$ & $63[13]$ & $62[10]$ & $62[12]$ \\
\hline & Tr3 & $62[9]$ & $73 *[9]$ & $74[4]$ & $70[8]$ & $67[6]$ & $63[10]$ & $66[12]$ & $66[10]$ & $62[11]$ & $67[17]$ \\
\hline \multirow{3}{*}{$\begin{array}{l}\text { MAP } \\
\mathrm{mmHg}\end{array}$} & $\operatorname{Tr} 1$ & $72[4]$ & $89 *[15]$ & $87 *[10]$ & $91 *[11]$ & $86 *[14]$ & $94 *[29]$ & $87 *[15]$ & $82 *[11]$ & $79[11]$ & $79[11]$ \\
\hline & $\operatorname{Tr} 2$ & $76[7]$ & $89 *[13]$ & $88[12]$ & $86[16]$ & $82[13]$ & $82[13]$ & $81[11]$ & $80[15]$ & $78[12]$ & $78[14]$ \\
\hline & $\operatorname{Tr} 3$ & $77[9]$ & $89 *[8]$ & $90 *[3]$ & $86 *[8]$ & $84 *[7]$ & $81 *[12]$ & $83[13]$ & $83[11]$ & $80[13]$ & $91[13]$ \\
\hline
\end{tabular}

*Significantly $(\mathrm{P}<0.05)$ different from baseline data within each time. HR - Heart Rate; $\mathrm{f}_{\mathrm{R}}-$ Respiratory Rate; SAP - Systolic Arterial Pressure; DAP - Diastolic Arterial Pressure; MAP- Mean Arterial Pressure. 
study, GIORGI et al. (2007) observed the presence of tachycardia in $100 \%$ of the animals that received $5 \mathrm{mg}$ $\mathrm{kg}^{-1}$ of tramadol IV.

There were no significant differences in $f_{R}$ when comparing the doses of tramadol in $\operatorname{Tr} 1$ or $\operatorname{Tr} 2$. However, the $\operatorname{Tr} 3$ had a significant increase in the $f_{R}$ at T5 $(\mathrm{P}=0.025)$ and remained above the basal values during the first hour of evaluation (T10: $\mathrm{P}=0.032$; T20: $p=0.02$; $T 60: P=0.04)$. An increase in $f_{R}$ was also described by DHANJAL et al. (2009) when injecting cumulative doses of tramadol intravenously in horses. The cause of the increase in $f_{R}$ remains unknown. However, it is believed that this increase may be associated with the secondary stimulation of the central nervous system.

One of the animals from the $\operatorname{Tr} 1$ showed a sudden increase in the $f_{R}$ (from 36 to 96 breaths per minute) at T60. This increase was associated with spasmodic contractions localized on the left flank region and in synchrony with the HR, suggesting synchronous diaphragmatic flutter. As reported by MANSMANN et al. (1974), the accentuated excitement may have contributed to the appearance of such alterations. There are no reports of diaphragmatic flutter being triggered in horses by the administration of opioids in the literature. However, in human beings, the appearance of diaphragmatic myoclonus after the use of $\mu$ agonist opioids was described (LAUTERBACH et al., 1999).

Blood pressures (SAP, MAP and DAP) increased 5 minutes after tramadol administration at the three doses studied. It is believed that the increase in arterial pressure may be directly associated with the stimulation of the sympathetic activity, due to the modulation and re-uptake of the monoamines triggered by the drug, especially of noradrenalin, as shown by SHIN et al. (2006). However the values remained in the range considered normal for the horses. No statistical differences were found among the treatments (Table 1).

Interestingly, even though no statistical differences among the treatments were noted $(\mathrm{P}>0.05)$, the alterations in the SAP, DAP, and MAP in the Tr1 did last longer than in the other treatments, mainly when compared to the $3 \mathrm{mg} \mathrm{kg}^{-1}$ dose. This finding may be related to the dose-depressant hemodynamic effects triggered by the tramadol. Despite the fact that the mechanisms are not completely clear, it is known that such in vivo effects are caused by vascular, myocardial and nervous alterations. Whereas lower doses of tramadol can cause a transitory increase in arterial pressure with a concomitant increase in the noradrenalin concentrations, high doses of the drug can lead to vasodilatation through the production of nitric oxide and to effects on smooth muscle tissue, with a consequent decrease in arterial pressure (NAGAOKA et al., 2002).

The gastrointestinal motility scores decreased significantly in the $\operatorname{Tr} 2$ (T20) and persisted for 60 minutes [Score median baseline $11(11 / 16)$; score median T20-T60: 8 (8/16)], $(\mathrm{P}<0.05)$. However, there was no statistical difference among tramadol treatments. The transitory decrease in the scores of GI motility was similar to the findings described by DHANJAL et al. (2009), who found that after the administration of $1.6 \mathrm{mg} \mathrm{kg}^{-1}$ of tramadol, there was a significant decrease in GI motility, persisting for 40 minutes. In accordance with WILDER-SMITH \& BETTIGA (1997), the interference of tramadol with GI motility is related to the direct influence of the drug over the myenteric plexus by the central modulation via opioid or by monoaminergic mechanisms. The mild and transitory decrease in GI motility observe in this study suggests the advantage of the use of tramadol over other opioids such as morphine (BOSCAN et al., 2006) in horses.

Tramadol, regardless of the administered dose, did not cause any evident sedation as measured by a percentage difference in the head height.Using the same method, DHANJAL et al. (2009) also observed an absence of sedation, regardless of the dose of tramadol used.

The administered doses of tramadol did not change the MNT. No significant differences were observed among the treatments or over time when compared to the baseline values of each treatment (Figure 1).The method used to evaluate the MNT was based on the absence of studies using mechanical stimuli to evaluate the effects of tramadol in horses. Considering the differences in excitability of the nociceptors, depending on the type of stimulus, it was hypothesized that results different from those already published in other studies would be observed. The maximum weight applied (1000gf) was determined considering the no evidence of tissue injury reported by KUKANIC et al. (2005), using the similar technique in carpal pad dogs. The repeatability of the stimulus and the alteration in the mechanical threshold were some of our concerns and they are part of the limitations of the von Frey method. However, for the studies we based on papers written before that attest the feasibility of the technique. The choice of the coronary band based on the sensitivity of the region and easier evaluation of the withdrawal when pressure was exerted. Data regarding the mechanical threshold evaluation in palmar region in horses were 


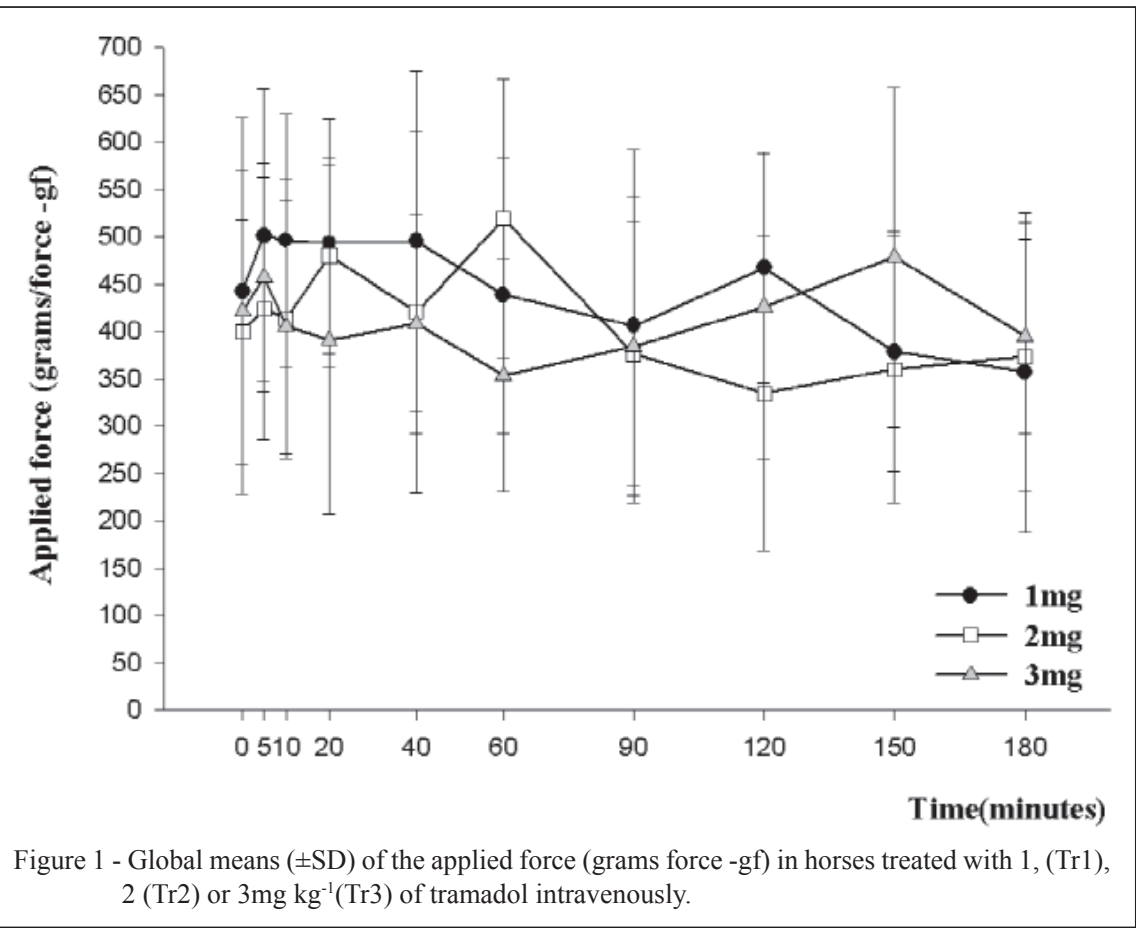

not reported. However, studies performed using von Frey filaments on another body region were described as well tolerated and feasible in horses (RÉDUA et al., 2002; OLESKOVICZ et al., 2006).

Similar results founded in this study were described by DHANJAL et al. (2009) when using thermal stimulation to evaluate the effects of tramadol in horses, with no alterations in the thermal threshold. According to the authors, such results would be related to the type of nociceptive fiber involved and the stimulation of A-delta fibers by the thermal method was most likely unaffected by the tramadol. A similar argument was applied to the present study. The mechanical stimulation by the von Frey method, when used on healthy tissues, would act preferably on type A fibers (LE BARS et al., 2001), and clinical doses of $\mu$ agonist opioids would primarily diminish the activity of type C fibers (JURNA \& HEINZ, 1979). However, studies in dogs (KUKANICH et al., 2005; KUKANICH \& PAPICH, 2011) have revealed the nociceptive effects of $\mu$ opioid agonists in animals with no tissue lesions by using mechanical stimuli, which would support the use of the von Frey method in this study.

The route of administration may also influence the absence of the effects of the tramadol over the MNT. As opposed to the presented results, other studies indicate that tramadol, when administered by epidural injection, may have a higher analgesic potential in horses (NATALINI \& ROBINSON;
2000). Using the electrical stimulation method, the authors observed long-duration analgesia after the administration of a $1 \mathrm{mg} \mathrm{kg}^{-1}$. Despite that fact, no pharmacokinetics studies compare the intravenous and the epidural methods of administration or associate such results with the clinical effects.

Behavioral alterations of different intensities occurred in the three treatments and were more evident during the administration of the drug and even after the first 20 minutes. The alterations were more pronounced in the Tr3. At this treatment, the main findings were lip droop (3/7), light contractions of the pectoral and lumbar muscles $(3 / 7)$, general muscular contraction (2/7), drooling (1/7), ataxia $(1 / 7)$ and stereotyped head movements. In the other treatments, the main alterations were the presence of lip droop (Tr2: 1/7; $\operatorname{Tr} 33 / 7$ ), light contractions of the pectoral muscles $(2 / 7$ in each treatment) and ataxia in only one (1/7) $\operatorname{Tr} 2$ horse.

The observed behavioral alterations agreed with the findings of DHANJAL et al. (2009), who described that IV tramadol administration in horses did not produce the classical effects of opioids, such as the act of digging and roaming in circles. However, muscle tremors were present in all the treatments, similar to what was described by other authors who used $\mu$ opioid agonists (GIORGI et al., 2007; DHANJAL et al., 2009; KNYCH et al., 2013). It is believed that the decrease in the behavioral effects was due to the method of administration used in this 
study, the dilution of the drug and the increased time of infusion, proposed by SHILO et al. (2007). The adverse effects resolved by 20 minutes post tramadol administration, probably associated a rapid decline in plasma tramadol concentrations as reported by $\mathrm{KNYCH}$ et al. (2013) for similarly doses evaluated in this study.

It was concluded that the clinical alterations induced by the IV administration of tramadol in the doses of 1,2 and $3 \mathrm{mg} \mathrm{kg}^{-1}$ are light and transitory. However, in this model, tramadol did not have a mechanical antinociceptive effect at any of the evaluated doses.

\section{ACKNOWLEDGEMENTS}

The authors thank Capes, Guabi Nutrição Animal and Dr. Karina Yazbek from the Agener União Química for their support in the execution of this study.

\section{SOURCES AND MANUFACTURERS}

a- Cloridrato de Tramadol 50mg/mL; União Química Farmacêutica, São Paulo, Brazil.

b- Samtronic Infusion Systems, São Paulo, SP, Brazil.

c- ECG - TEB - ECGPC, São Paulo, Brazil.

d- Multi-parametric monitor DX 2022 DIXTAL, Brazil.

e- Analgesímetro Digital, INSIGHT, SãoPaulo, Brazil.

\section{BIOETHICS AND BIOSSECURITY COMMITTEE}

(Protocol 27/10)

\section{REFERENCES}

BOSCAN, P. et al. Evaluation of the effects of the opioid agonist morphine on gastrointestinal tract function in horses. American Journal of Veterinary Research, v.67, p.992-997, 2006 Available from: <http://avmajournals.avma.org/doi/abs/10.2460/ ajvr.67.6.992?url ver=Z39.88-2003\&rfr id=ori:rid:crossref. org\&rfr_dat=cr>. Accessed: set 2013. doi: 10.2460/ajvr.67.6.992.

CUNHA, T.M. et al. An electronic pressure-meter nociception paw test for mice. Brazilian Journal of Medical and Biological Research, v.37, p.401-407, 2004. Available from: <http://www. scielo.br/pdf/bjmbr/v37n3/5164.pdf $>$. Accessed: set 2013.

DENADAI-SOUZA, A. et al. Participation of peripheral tachykinin NK1 receptors in the carrageenan-induced inflammation of the rat temporomandibular joint. European Journal of Pain, v.13, p.812-819, 2009. Available from: <http://onlinelibrary.wiley.com/ doi/10.1016/j.ejpain.2008.09.012/abstract;jsessionid=0122E8A B611C0A96EE07572BFF8E1FC2.f01t03>. Accessed: set 2013. doi:10.1016/j.ejpain.2008.09.012.

DHANJAL, J.K. et al. Intravenous tramadol: effects, nociceptive properties, and pharmacokinetics in horses. Veterinary Anaesthesia and Analgesia, v.36, n.6, p.581-590, 2009. Available from: <http:// onlinelibrary.wiley.com/doi/10.1111/j.1467-2995.2009.00492.x/>. Accessed: set 2013. doi: 10.1111/j.1467-2995.2009.00492.x.
DUQUE, J.C. et al. Pre-emptive epidural ketamine or $\mathrm{S}$ $(+)$-ketamine in post-incisional pain in dogs: a comparative study. Veterinary Surgery, v.33, p.361-367, 2004. Available from: <http:// onlinelibrary.wiley.com/doi/10.1111/j.1532-950X.2004.04052.x/ pdf $>$. Accessed: set 2013.

GIORGI, M. et al. Pharmacokinetics of tramadol after epidural administration in horses. Journal of Equine Veterinary Science, v.30, n.1, p.44-46, 2010. Available from: <http://www. sciencedirect.com/science/article/pii/S073708060900690X >. Accessed: set 2013. doi: :10.1016/j.jevs.2009.11.004.

GIORGI, M. et al. Pharmacokinetics of tramadol and its metabolites M1, M2 and M5 in horses following intravenous, immediate release (fasted/fed) and sustained release single dose administration. Journal of Equine Veterinary Science, v.27, n.1, p.467-512, 2007. Available from: <http://www.sciencedirect.com/ science/article/pii/S0737080607003425>. Accessed: set 2013. doi: 10.1016/j.jevs.2007.10.004.

HAUSSLER, K.K.; ERB, H.N. Pressure algometry for the detection of induced back pain in horses: a preliminary study. Equine Veterinary Journal, v.38, n.1, p.76-81, 2006. Available from: $<$ http://onlinelibrary.wiley.com/doi/10.2746/042516406775374225/ pdf $>$. Accessed: set 2013.

KNYCH, H.K. et al. Pharmacokinetics and selected pharmacodynamic effects of tramadol following intravenous administration to the horse. Equine Veterinary Journal, v.45, p.490-496, 2013. Available from: <http://onlinelibrary.wiley.com/ doi/10.1111/j.2042-3306.2012.00688.x>. Accessed: set 2013. doi: 10.1111/j.2042-3306.2012.00688.x

KUKANICH, B. et al. Use of von Frey device for evaluation of pharmacokinetics and pharmacodynamics of morphine after intravenous administration as an infusion or multiple doses in dogs. American Journal of Veterinary Research, v.66, p.1968-1974, 2005. Available from: $<$ http://avmajournals.avma.org $>$. Accessed: set 2013. doi: 10.2460/ajvr.2005.66.1968.

KUKANICH, B.; PAPICH, M.G. Pharmacokinetics and antinociceptive effects of oral tramadol hydrochloride administration in Greyhounds. American Journal of Veterinary Research, v.72, p.256-262, 2011. Available from: <http:// avmajournals.avma.org/doi/pdf/10.2460/ajvr.72.2.256>. Accessed: set 2013. doi: 10.2460/ajvr.72.2.256.

LAUTERBACH, E.C. Hiccup and apparent myoclonus after hydrocodone: review of the opiate-related hiccup and myoclonus literature. Clinical Neuropharmacology, v.22, p.87-92, 1999. Available from: <http://journals.lww.com/clinicalneuropharm/ Abstract/1999/03000/Hiccup_and_Apparent_Myoclonus_ After_Hydrocodone_.4.aspx $>$. Accessed: set 2013 . do i: 10.1097/00002826-199903000-00004.

LE BARS, D. et al. Animal models of nociception. Pharmacological Review, v.53, p.597-652, 2001. Available from: <http://pharmrev. aspetjournals.org/content/53/4/597.full.pdf $+\mathrm{html}>$. Accessed: set 2013.

MANSMANN, R.A.et al. Synchronous diaphragmatic flutter in horses. American Veterinary Medical Association, v.165, p.265$270,1974$.

NAGAOKA, E.et al. Tramadol has no effect on cortical renal blood flow-despite increased serum catecholamine levels-in anesthetized rats: implications for analgesia in renal insufficiency. Anesthesia 
and Analgesia, v.94, p.619-625, 2002. Available from: <http:// journals.lww.com/anesthesia-analgesia/Fulltext/2002/03000>. Accessed: set 2013. doi: 10.1097/00000539-200203000-00026.

NATALINI, C.C.; ROBINSON, E.P. Effects of epidural opioid analgesics on heart rate, arterial blood pressure,respiratory rate, body temperature and behavior in horses. Veterinary Therapeutics, v.4, n.4, p.364-375, 2003.

NATALINI, C.C.; ROBINSON, E.P. Evaluation of the analgesic effects of epidurally administered morphine, alfentanil, butorphanol, tramadol, and $\mathrm{U} 50488 \mathrm{H}$ in horses. American Journal of Veterinary Research, v.61, n.12, p.1579-1586, 2000. Available from: <http://avmajournals.avma.org/doi/pdf/10.2460/ ajvr.2000.61.1579>. Accessed: set 2013. doi: 10.2460/ ajvr.2000.61.1579.

OLESKOVICZ, N. et al. Preemptive effects of epidural S (+) ketamine in the horse's postincisional pain. Brazilian Journal of Veterinary Research and Animal Science, v.43, p.24-32, 2006. Available from: <http://bases.bireme.br/cgi-bin/wxislind.exe/iah/ online/?IsisScript=iah/iah.xis\&src $=$ google \&base $=$ LILACS\&lan $\mathrm{g}=\mathrm{p} \&$ nextAction $=\operatorname{lnk} \&$ exprSearch $=453751 \&$ index Search $=\mathrm{ID}>$. Accessed: set 2013.

RÉDUA, M.A. et al. The pre-emptive effect of epidural ketamine on wound sensitivity in horses tested by using von Frey filaments. Veterinary Anesthesia and Analgesia, v.29, p.1-7, 2002. Available from: <http://onlinelibrary.wiley.com>. Accessed: set 2013. doi: 10.1046/j.1467-2995.2002.00083.x.
RINGER S.K. et al. Development of a xylazine constant rate infusion with or without butorphanol for standing sedation of horses. Veterinary Anaesthesia and Analgesia, v.39, p.1-11, 2012. Available from: <http://onlinelibrary.wiley.com/doi/10.1111/j.14672995.2011.00653.x/>. Accessed: set 2013. doi: 10.1111/j.14672995.2011.00653.x.

SHILO, Y. et al. Pharmacokinetics of tramadol in horses after intravenous, intramuscular and oral administration. Journal of Veterinary Pharmacology and Therapeutics, v.31, n.1, p.60-65, 2008. Available from: $<$ http://onlinelibrary.wiley.com/doi/10.1111/ j.1365-2885.2007.00929.x/abstract>. Accessed: set 2013. doi: 10.1111/j.1365-2885.2007.00929.x.

SHIN, I.W. et al. A supraclinical dose of tramadol stereoselectively attenuates endothelium-dependent relaxation in isolated rat aorta. Anesthesia and Analgesia, v.103, p.366-371, 2002. Available from: <http://europepmc.org/abstract/MED/16861418>. Accessed: set 2013. doi: 10.1213/01.ane.0000225913.64876.d2.

SINGH, S. et al. Modification of cardiopulmonary and intestinal motility effects of xylazine with glycopyrrolate in horses. Canadian Journal Veterinary Research, v.61, n.2, p. 99-107, 1997. Available from: <http://www.ncbi.nlm.nih.gov/pmc/articles/ PMC1189385/pdf/cjvetres00018-0021.pdf>. Accessed: set 2013.

WILDER-SMITH, C.H.; BETTIGA, A. The analgesic tramadol has minimal effect on gastrointestinal motor function. British Pharmacological Society, v.43, p.71-75, 1997. . Available from: $<$ http://onlinelibrary.wiley.com/doi/10.1111/j.1365-2125.1997. tb00140.x/pdf $>$. Accessed: set 2013. 